\title{
FACT, VALUE AND THEORY IN ANTITRUST ADJUDICATION
}

\author{
HERBERT HOVENKAMP*
}

Once again, I thank the Duke Law Journal for providing space for a brief answer to Professor Liebeler's response ${ }^{1}$ to some of my earlier work. ${ }^{2}$

Professor Liebeler's title, "What are the Alternatives to Chicago?," is apparently a rhetorical question. Ostensibly the answer is "None." I write a few lines merely to emphasize once again that the alternatives are real, obvious, and even necessary to the preservation of antitrust in a democratic society.

In Antitrust Policy After Chicago, I argued, at some length, that the Chicago approach to antitrust analysis does not represent the "discovery" of an econoinic approach to antitrust, but rather a simple change in economic models; ${ }^{3}$ that the public, or pohicy, purpose of economics is not to eliminate distributive justice as a concern, but only to enable policymakers to assess the social cost of alteruative pohicies; ${ }^{4}$ that the neoclassical economic nodel used by the Chicago School exaggerates the ease with which efficiency can be identified in the real world, and that when efficiency becoines more difficult to identify political concerns looin relatively larger; ${ }^{5}$ that Chicago School antitrust policy is just as "political" as the alternatives; ${ }^{6}$ that Chicago School antitrust, its claims to science notwithstanding, rests on assumptions that are as unverifiable as the assumptions of others, and that the entire theory of the social cost of monopoly is ultinately unprovable; ${ }^{7}$ that free riding may be so pervasive that it is inpossible to ineasure consuiner preference froin consuiner behavior; 8 that one calmot construct an antitrust pohicy based exclusively

* Professor of Law, University of Iowa.

1. Liebeler, What are the Alternatives to Chicago?, 1987 DukE L.J. 801.

2. Principally, Hovenkamp, Chicago and Its Alternatives, 1986 DUKE L.J. 1014 [hereinafter Hovenkamp, Alternatives]; Hovenkamp, Rhetoric and Skepticism in Antitrust Argument, 84 Mich. L. REv. 1721 (1986); Hovenkamp, Antitrust Policy After Chicago, 84 Mich. L. REV. 213 (1985) [hereinafter Hovenkamp, After Chicago].

3. Hovenkamp, After Chicago, supra note 2, at 217-26.

4. Id. at 224 .

5. Id. at 224-26.

6. Id. at 231-32.

7. Id. at 236-37; see Hovenkamp, Treble Damages Reform, ANTITRUST BULL. 1988 (forthcoming).

8. Hovenkamp, After Chicago, supra note 2, at 243. 
on efficiency; ${ }^{9}$ that the Chicago School refuses to take the legislative history of the antitrust laws seriously; ${ }^{10}$ and that the Chicago School tends to rely on static models which underestimate the extent of strategic behavior." I concluded by defending the jury verdicts in two recent antitrust cases-Aspen Skiing Co. v. Aspen Highlands Skiing Corp. ${ }^{12}$ and Bonjorno v. Kaiser Aluminum \& Chemical Corp. ${ }^{13}$-arguing that both cases involved plausible instances of anticompetitive strategic behavior. ${ }^{14}$ In his response, Professor Liebeler discusses that conclusion alonemaking no reference to the other issues, which I believe to be far more important. I assume by his silence that he agrees with me on all the other points. If that is so, I do not know why we are bothering to debate the rest.

\section{The Consumer Welfare Model, Theoretical Facts AND JuRy Prerogative}

Professor Liebeler focuses on my defense of the juries' findings of anticompetitive behavior in Aspen Skiing and Bonjorno. He concludes that, as between alternative explanations for the defendant's behavior in Aspen Skiing, the anticompetitive one "seems not to be the case"-even assuming Aspen Skiing Company (Ski Co) was a monopolist. ${ }^{15} \mathrm{He}$ then discusses Bonjorno in a similar way. ${ }^{16}$ My general response to Professor Liebeler is something I have said before. ${ }^{17}$ The question in both Aspen Skiing and Bonjorno was not whether the plaintiffs were entitled to summary judgment on their records. If that had been the issue, I noted, I would have had no trouble deciding that summary judgment was inappropriate. ${ }^{18}$ Rather, the question in both cases was whether there was a conflict in the facts or in the theories from which juries are permitted to choose, and whether the juries were entitled to accept a theory that condemned the defendants' activities. ${ }^{19}$ A unanimous Supreme Court in Aspen Skiing, ${ }^{20}$ as well as the United States Court of Appeals for the Third Circuit in Bonjorno, ${ }^{21}$ answered yes to both questions.

\footnotetext{
9. Id. at $246-48$.

10. Id. at 249-55.

11. Id. at $256-83$.

12. 472 U.S. 585 (1985).

13. 752 F.2d 802 (3d Cir. 1984), cert. denied, 106 S. Ct. 3284 (1986).

14. Hovenkamp, After Chicago, supra note 2, at 270-83.

15. Liebeler, supra note 1 , at 808 .

16. Id. at $814-15$.

17. Hovenkamp, Alternatives, supra note 2, at 1015.

18. Id.

19. Id. at 1015-16.

20. 472 U.S. at $587,611$.

21. 752 F.2d at 811 .
} 
Professor Liebeler suggests one explanation of defendant Ski Co's possibly inefficient behavior-Ski Co was taking advantage of its and Highlands' established positions to extract quasi-rents from Highlands. ${ }^{22}$ He concludes, however, that this "seems not to be the case," for two of Ski Co's mountains-Buttermilk and Snowmass-were facilities identical to Highlands. ${ }^{23}$ I believe Professor Liebeler is wrong. Had the slopes been identical, skiers would have been indifferent as to whether Highlands was included in the package with Buttermilk and Snowmass. For example, a shopper purchasing a single box of crackers should be indifferent as to whether the store's inventory includes ten, fifty, or one hundred identical boxes-as long as she gets one. The Aspen Skiing Court, however, cited evidence to the contrary. ${ }^{24}$ The fact that customers believed Highlands was different from Ski Co's three mountains makes the expropriation of quasi-rents at least theoretically possible. Highlands needed Aspen to attract destination skiers; therefore Ski Co could force an arrangement on Highlands that at the margin deprived Highlands of a return on the fixed cost part of its investment. Presumably Highlands would stop operating before agreeing to an arrangement that denied it recovery of its variable costs. This supports the jury verdict in Aspen Skiing even under Professor Liebeler's theory of antitrust, unless he believes that the strategic appropriation of quasi-rents should never be illegal, even if it is inefficient. ${ }^{25}$

But all of this misses the main point: Liebeler's conclusion that as between alternative explanations the anticompetitive one "seems not to be the case" is not preclusive on juries. Juries are generally entitled to look at the same set of alternatives and vote the other way. Professor Liebeler apparently believes that the "consumer welfare model"-upon which he bases his analysis-describes a theory of antitrust that is so determinate and uncontroversial that the only role remaining to juries is

22. Liebeler, supra note 1 , at 808-09.

23. Id.

24. 472 U.S. at 606.

25. For an analysis of quasi-rent appropriation, see Klein, Crawford \& Alchian, Vertical Integration, Appropriable Rents, and the Competitive Contracting Process, 21 J.L. \& Econ. 297 (1978). A mere extraction of quasi-rents, provided it is computed precisely, is a wealth transfer and has no welfare effects other than transaction costs. Transaction costs, however, in settings where quasirents can be extracted may be very high. Bilateral monopoly is one such situation. See R. BLAIR \& D. KASERMAN, LAW AND ECONOMICS OF VERTICAL INTEGRATION AND CONTROL 31-36 (1983) (introducing mathematical model to prove that total industry profits decrease due to "successive monopoly"). But see Friedman, Antitrust Analysis and Bilateral Monopoly, 1986 WIS. L. REV. 873, 906-08 (Each firm in a bilateral monopoly is "likely to realize that if it bargains on both price and quantity a beneficial deal is more likely."). Joint ownership of a monopoly facility, as the Court presumed to be the case in Aspen Skiing, is another situation in which transaction costs may be very high. For similar situations, see Sterk, Neighbors in American Land Law, 87 ColuM. L. REv. 55, 69-88 (1987). 
to decide disputed adjudicative facts, such as which of two witnesses was telling the truth. I believe that, even in antitrust cases, juries continue to have a broader role in fact determination.

The core of my disagreement with Professor Liebeler has to do with the relative role of fact, theory and jury prerogative in antitrust policy. As a basic premise, of course, juries decide issues of fact in jury trials. Admittedly, we sometimes take questions about adjudicative facts ${ }^{26}$ that is, facts about the parties in the case-away from antitrust juries because we say that no reasonable jury could ever find in the plaintiff's favor on the particular set of facts. The Supreme Court and the Third Circuit found Aspen Skiing and Bonjorno not to be such cases.

But was a rational juror entitled to conclude from the adjudicative facts in Aspen Skiing and Bonjorno that the defendants' behavior was anticompetitve, inefficient, or socially harmful?27 Deciding this depends not only on the jurors' perception of the adjudicative facts, but also on their entitlement to rely on a more abstract set of facts that concern the economic consequences of specific behavior.

\section{A. Theoretical Facts.}

Both Aspen Skiing and Bonjorno involve relatively complex factsbut even more complex and controversial economic theories. Aspen Skiing involves a firm's strategic behavior directed at competitors. Bonjorno involves the relationship between vertical integration, sunk costs, quasirents and the resulting opportunities for strategic behavior. Professor Liebeler has offered an interpretation of the facts and a set of theories suggesting that the juries in both cases were wrong and that the defendants should have won. ${ }^{28}$ Although I find Liebeler's explanations relatively attractive and quite reasonable, he fails to address the real issue respecting the use of economic theory in litigation-whether the juries were obliged to accept Liebeler's theories or some other theories that do not fit into the prevailing model quite as well. I suggest two things here. First, judges must invariably control theory to a substantial degree, and second, within a fairly broad range, juries must nevertheless have the right to select among competing theories just as they select among competing adjudicative facts.

On a fundamental level, theories look more like facts than law-but at a much higher level of abstraction than are most common facts. Theoretical statements purport to be descriptive of the world, not statements

26. See $3 \mathrm{~K}$. Davis, Administrative Law Treatise $\$ 15.3$, at 143-46 (2d ed. 1980).

27. In more legal terms, the issue is whether a rational juror was entitled to believe that the defendants had monopolized or attempted to monopolize certain markets.

28. Liebeler, supra note 1 , at 805-10, 812-15. 
of rules made by the sovereign. Because facts generally go to the jury and I am defending the jury verdicts in Aspen Skiing and Bonjorno, I might be tempted to let the matter rest with the observation that theories are more like facts than like law. I cannot, however, because the question is too complicated and interesting.

"Legislative" facts and, in the case of judge made law, "judgmental" facts are also highly abstract. ${ }^{29}$ When dealing with these facts, federal judges are permitted (but not required) to resolve conflicts themselves, consulting any authority, whether produced by the parties or from some other source. ${ }^{30}$ Juries, however, may also resolve such conflicts.

Theoretical propositions that appear to be descriptive of the real world are within the realm of judgmental facts. These propositions look like assertions but are much inore abstract than the particular facts of the case. At the risk of misstating Professor Liebeler's position, he appears to suggest two theoretical propositions about Aspen Skiing and Bonjorno: (1) a monopolist's refusal to deal with a weaker competitor is never socially costly, and (2) a firm's refusal to deal with a vertically related firm is never socially costly. ${ }^{31}$ If these two statements are so incontrovertibly true that juries should not be permitted to decide to the contrary, then Mr. Liebeler's criticisms of Aspen Skiing and Bonjorno are correct. I do not believe that either statement falls into that category.

Admittedly these propositions are different from the facts commonly in dispute in litigation, such as "was the dog provoked" or "did the defendant fall asleep at the wheel." Nevertheless, they are factual in that they purport to describe the world. What makes these two factual statements problematic, however, is that, given the current state of economic science, they cannot be verified or falsified. Mr. Liebeler might feel very strongly that they are true, and he might be able to design a model illustrating them to be true, but other, equally reasonable people might employ a different model that allows some exceptions to the two statements. ${ }^{32}$ Still otliers might decide that as basic propositions the two statements are simply wrong. Juries must be permitted to choose among conflicting theoretical propositions-just as they choose among alternative explanations in other factual disputes.

29. See $3 \mathrm{~K}$. DAVIS, supra note $26, \S 15.10$, at 178 . Judgmental facts are facts "mixed with judgment, policy ideas, opinion, discretion or philosophical preference." Id.

30. See FED. R. Evid. 201 advisory committee's note to subdivision (b).

31. To this second proposition, one may wish to add the clause "unless the refusal to deal facilitates horizontal collusion." One also may wish to add further refinements or qualifications, or perhaps to substitute the word "anticompetitive" or "inefficient" for the words "socially costly," but such changes would not be germane to my point.

32. E.g., Krattenmaker \& Salop, Anticompetitive Exclusion: Raising Rivals' Costs to Achieve Power over Price, 96 YALE L.J. 209 (1986). 


\section{B. The Consumer Welfare Model.}

The consumer welfare principle-articulated by a popularizer of Chicago-style neoclassicism, Robert Bork ${ }^{33}$-is undoubtedly one of the two or three greatest epithets in the antitrust lexicon. But there is considerable sleight of hand in Judge Bork's statement of the principle and in the way other Chicagoans use it. As a general statement of the goal of the antitrust laws, the consumer welfare principle is indisputably true. Beyond that point, however, the analytic value of the principle becomes much more diffuse. The consumer welfare principle does not dictate that neoclassical models are better than postclassical ones. It tells us only that productive efficiency is good and that the antitrust laws should maximize allocative efficiency without disturbing productive efficiency any more than necessary. ${ }^{34}$ Such a directive is little more than the economists" version of "do justice."

Nevertheless, Professor Liebeler attacks me for not adhering to the consumer welfare principle. He fails to understand that the consumer welfare principle itself is indeterminate with respect to many issues, including those in Aspen Skiing and Bonjorno. As the discussion below reveals, ${ }^{35}$ the consumer welfare principle can even be indeterminate with respect to one of the Chicago School's favorite theories-resale price maintenance to control free riding by marginal dealers is efficient because it increases welfare. ${ }^{36}$

\section{The Judicial Role.}

A difficult question that needs to be worked out-and this essay offers no more than a statement of the problem-is what the role of the generalist judge should be in turning questions about economic theory into questions of law or matters of policy where the legislature has not incorporated a particular theory into the statute at issue. ${ }^{37}$ In other

33. See R. Bork, The Antitrust Paradox (1978).

34. See id. at 91 .

35. See infra text accompanying notes $50-64$.

36. See R. BORK, supra note 33, at 280-98.

37. On the problem in general, see FCC v. National Citizens Comm. for Broadcasting, 436 U.S. 775, 813-14 (1978); $3 \mathrm{~K}$. DAvis, supra note 26, $\S 15.9$; Davis, "There is a Book Out . ..": An Analysis of Judicial Absorption of Legislative Facts, 100 HARV. L. REv. 1539, 1547-92 (1987); Monahan \& Walker, Social Authority: Obtaining, Evaluating, and Establishing Social Science in Law, 134 U. PA. L. REv. 477, 498-508 (1986).

Questions of theory in private plaintiff actions under the Sherman Act are particularly tricky. The statute is dated and short, and Congress has told us almost nothing about the kind of economic theory that should be employed in determining when behavior violates the statute. Judge Bork has suggested that the framers of the Sherman Act wrote neoclassical economic theory and its concept of efficiency into the Sherman Act. See R. BoRK, supra note 33, at 56-71 (overriding policy goal behind Sherman Act is consumer welfare); Bork, Legislative Intent and the Policy of the Sherman 
words, when should the judge decide that the court, rather than the jury, should determine whether these "facts" are true or false?"38

Several possible rules might govern the judge's role respecting matters of theory: (1) questions of theory should always be a matter of law; or (2) a jury should be entitled to select among conflicting theories as long as each theory is at least minimally plausible; or (3) matters of theory are ordinarily questions of fact but may become questions of law if a theoretical issue becomes sufficiently well settled that the plausibility of alternatives is not worth litigating.

A strong case can be made for the third choice-turning theory questions into questions of law once the theoretical issue becomes wellsettled. Too many academics (not only Chicagoans), however, at least implicitly prefer the first choice ${ }^{39}$-treating all theory questions as matters of law-because it gives prettier results.

The problems associated with changing theory questions into questions of law are particularly acute in antitrust matters because of the indetermmate nature of economic policy statements. Within a particular model based on a given set of assumptions, it can be quite easy-and extraordinarily convimcing - to draw a conclusion such as "resale price maintenance is never anticompetitive unless it facilitates collusion," or "creation of monopoly by predatory pricing is impossible." But these statements are themselves neither verifiable nor falsifiable, and neither are the models from which they are derived. At one time or another, economists or groups of economists in power may dispute these statements or assent to them with varying degrees of enthusiasm, but this is as much a function of which way the pohtical or academic winds are blowing as of empirical certainty.

Despite the problems associated with changing questions of theory into questions of law, judges have a wide range of mechamisms available to take issues of theory away from juries. One of the most controversial mechanisms in antitrust litigation has been summary judgment. In two recent decisions, Matsushita Electric Industrial Co. v. Zenith Radio

Act, 9 J.L. \& EcoN. 7, 7-8 (1966) (goal of Sherman Act is maximization of wealth). Judge Bork's view, however, has not withstood criticism very well. See generally Hovenkamp, After Chicago, supra note 2, at 249-50 ("legislative histories of the various antitrust laws fail to exhibit anything resembling a dominant concern for economic efficiency"); Lande, Wealth Transfers as the Original and Primary Concern of Antitrust: The Efficiency Interpretation Challenged, 34 HASTINGs L.J. 65, 83-89 (1982) (arguing it is very unlikely that in 1890 Congress understood the impact of monopoly power on consumer welfare).

38. For a proposal that social science data should be treated as "social authority" and the judge's conclusions as conclusions of law, see Monahan \& Walker, supra note 37, at 495-517.

39. For a generalized argument on the first proposition, see $i d$. at 478-79. 
Corp. ${ }^{40}$ and Cargill, Inc. v. Monfort of Colorado, Inc., ${ }^{41}$ the Supreme Court has developed a rule for summary judgment in antitrust cases-to avoid unfavorable summary judgment, the plaintiff must produce evidence that makes it "more likely than not" that its version of things is true.

Unfortunately, Matsushita and Cargill tell us little about how this rule applies to questions of theory rather than questions of adjudicative fact. The rule seems to apply best to adjudicative facts. For example, to avoid summary judgment in a case alleging conspiracy among the defendants, the plaintiff must present evidence suggesting that "more likely than not" the defendants were conspiring. Even here, however, theory is important. Agreement can be inferred from market conduct, and such inferences might depend on fairly complex theoretical analyses of the rationality of firm behavior. ${ }^{42}$ Some footnotes in Cargill suggest that the summary judgment standard applies equally to theory and adjudicative facts. ${ }^{43}$ For example, a plaintiff who is trymg to avoid summary judgment by showing that "Inore likely than not" a merger will facilitate predatory pricing must produce some structural evidence that predatory pricing in the post merger market is plausible. On the theory that only dominant firms with available capacity and in inarkets with high entry barriers will pursue predatory pricing, part of the evidence would deal with entry barriers, excess capacity, and the market share of the post merger firm.

Neither Matsushita nor Cargill can be read to say that to avoid summary judgment one must show that a particular theory of predatory pricing or vertical integration or resale price mamtenance is "more likely than not" true. Rather, the decisions suggest that theory often becomes so well established that it dictates the kinds of facts that must be presented in an antitrust case. For example, today almost no one believes that predatory pricing is plausible except by dominant firms in markets with high entry barriers. This has prompted several tribunals to incorporate these beliefs into their predatory-pricing standards. ${ }^{44}$ Finding that

40. 475 U.S. 574, 585-88 (1986).

41. 107 S. Ct. $484,491-94$ (1986).

42. Matsushita involved such a theory. See 475 U.S. at 588-98; see also Apex Oil Co. v. DiMauro, 822 F.2d 246, 253-60 (2d Cir.) (alleging conspiracy that made performance of heating oil futures contracts impractical and expensive for plaintiff), cert. denied, $108 \mathrm{~S}$. Ct. 489 (1987).

43. $107 \mathrm{~S}$. Ct. at $494 \mathrm{nn} .15-17$. Cargill involved a motion to dismiss for failure to state a claim. The plaintiff never specifically alleged predatory pricing although the Court developed the theory of predatory pricing from the plaintiff's complaint. The Court essentially applied a summary judgment standard, concluding that "[e]ven had Monfort actually advanced a claim of predatory pricing, we doubt whether the facts as found by the District Court would have supported it." Id. at $494 \mathrm{n} .15$. The Court then discussed the theoretical basis for predatory pricing. Id.

44. See P. AReeda \& H. Hovinkamp, Antitrust Law ๆ 711.2b (1987 Supp.). 
well-established theory dictates the fact presentation of a particular case, however, is quite different from saying, for example, that among three conflicting but plausible theories the plaintiff must show that one is "more likely than not" the best explanation of the facts. In this sense, conflicting theories are like conflicting facts. Difficult as it may be, juries must choose among them.

Despite this reasoning, both judges and academics face a strong temptation to turn questions of theory into questions of law. They believe that the litigation process creates more predictable results in that way and minimizes the need for long, drawn-out trials in which experts are cross-examined and juries are left bewildered.

Antitrust may be anomalous in this respect. Policy shifts in antitrust go through relatively wide and frequent swings. One can be sure, for example, that if President Reagan is succeeded by a Democrat, someone greatly different from Bill Baxter will be named to head the Antitrust Division and people with different outlooks than Judges Posner, Bork, and Easterbrook will be nominated to the federal courts. These policy changes contribute greatly to the lack of predictability in antitrnst law. One has only to consider the fate of Warren Court antitrust jurisprudence since 1977.45 Juries, on the other hand, are selected inore or less at random, and there is no particular reason to think that a jury selected during a Republican administration is very different froin one selected during a Democratic administration. Within a single admimistration or antitrust regime, a relatively high number of rules of law may increase the predictability and consistency of antitrust adjudication. Over the long haul, however, we would probably have more stability if we left more things to juries.

One argument that theoretical facts should be treated as presenting questions of law is that such facts would then be reviewable de novo on appeal, because they are stated as conclusions of law. Adjudicative facts, on the other hand, are reviewable under a clearly erroneous standard, which permits the appellate court to second guess only irrational fact findings. Proponents of the argument for treating all theoretical issues as questions of law argue that trial judges should not be able to make economic or antitrust policy and insulate that policy from review by disguising it as merely "factual." 46

But their argument overlooks the fact that appellate courts as well as trial courts are able to einploy judgmental facts-in fact, appellate

45. See Continental T.V., Inc. v. GTE Sylvania Inc., 433 U.S. 36 (1977) (Burger Court adopts rule of reason for vertical nonprice restraints).

46. For a critique, see M. Saks, Judicial Attention to the Way the World Works: A Critique of "An Analysis of Judicial Absorption of Legislative Facts" (unpublished manuscript). 
courts probably do so more often. Furthermore, trial judges decide matters of legislative fact by not deciding them. The instant the trial judge in Aspen Skiing permitted the case to go to the jury, she had decided, whether or not she knew it, not to accept as a judgmental fact the proposition that "a monopolist's refusal to deal with a competitor is never socially costly." Either the court of appeals or the Supreme Court could later have disagreed and adopted a rule of law that would not allow such a question to go to the jury. In essence, the Supreme Court determined that the proposition was one upon which the jury was entitled to pass.

When a higher court gives such propositions to a jury it is simply conceding that it is not yet ready to turn the proposition into a rule of law, or part of the economic policy of antitrust. While this may produce some inconsistent results, over the long run it will produce no more inconsistency than if the antitrust courts of one regime adopt a particular policy rule while those of a different regime replace it with another.

If the theory in question is relatively uncontroversial, I believe judges should be willing to turn statements of theory into judgmental facts and thus into conclusions of law. Here, I suspect, is where a big part of my difference with Professor Liebeler hes. He has a high degree of faith in the neoclassical niodel, and he has used it to "demonstrate" all kinds of propositions about the consequences of vertical arrangements, pricing policies, horizontal integration, etc. ${ }^{47} \mathrm{I}$ agree with him about most of these things. ${ }^{48}$

But Liebeler has considerably less patience than I have with the possibility that other models, which appear just as rational to some people, can yield sharply different policy conclusions. The ideally democratic solution, of course, would be to convince Congress to legislate policies more explicitly. Unfortunately, because Congress has not been all that helpful, ${ }^{49}$ the judge is obliged to determine policy in an area where he is not necessarily that much better than the jury in deciding what the policy

47. E.g., Liebeler, 1984 Economic Review of Antitrust Developments: Horizontal Restrictions, Efficiency, and the Per Se Rule, 33 UCLA L. REv. 1019 (1986); Liebeler, 1983 Economic Review of Antitrust Developments: The Distinction Between Price and Nonprice Distribution Restrictions, 31 UCLA L. REv. 384 (1983); Liebeler, Intrabrand "Cartels" Under GTE Sylvania, 30 UCLA L. REv. 1 (1982).

48. See, e.g., H. HovenKamp, Economics AND FEDERAL ANTITRUST LAW $\S 9.2$, at 249-50 (1985) (discussing economics of resale price maintenance and citing Liebeler).

49. Congress continues to suggest that it prefers the per se rule for resale price maintenance, and it continues to balk at substantial antitrust reform as proposed by the Reagan administration. For example, in 1983 Congress placed a rider in the Antitrust Division's budget preventing the Division from arguing for the rule of reason in future private plaintiff resale price maintenance cases. Departments of Commerce, Justice, and State, the Judiciary, and Related Agencies Appropriations Act, 1984, Pub. L. No. 98-166, § 510, 97 Stat. 1071, 1102-03 (1983). 
should be and where mere rationality does not command one policy over all others.

Nevertheless, as dangerous and antidemocratic as it is, I am willing to accept the proposition that judges must intervene frequently with a policy decision, provided that the asserted policy is relatively uncontroversial among the relevant community of experts. Antitrust is fairly filled with such policy-based rules of law. For example, antitrust rules state that only dominant firms can be found guilty of monopolization, naked price fixing is socially costly, and mergers of firms with very small market shares are harmless. When substantial controversy exists in the expert community, however, it is better not to turn questions of theoretical fact into propositions of law too quickly. The Aspen Skiing and Bonjorno propositions stated above fall into that category.

\section{Hard Theories AND INDETERMINATE Models}

One problem with economic theories is that verifying or falsifying them is very difficult, often impossible. Professor Liebeler relies heavily, ${ }^{50}$ as I do, ${ }^{51}$ on a neoclassical model that illustrates quite easily that vertical arrangements are competitive except when they facilitate upstream or downstream collusion. But being able to diagram this result and being able to prove it are not the same thing. Important questions, such as whether output increases or decreases when resale price maintenance or a nonprice restraint is imposed, have proven distressingly difficult to answer. It is too difficult to isolate all the relevant variables. The empirical studies I know about have been elaborate, conjectural, inconclusive, and, worse yet, have tended to undermine the model as often as they support it. ${ }^{52}$

Perhaps even more serious is the problem of naive oversimplification that our models lead us to so easily, For example, ever since Professor

50. See sources cited supra note 47.

51. See, e.g., H. HovENKAMP, supra note $48, \S \S 8.1-9.4$ (discussing tie-in and resale price maintenance arrangements).

52. See Bureau of Competttion, Bureau of Economics, Federal Trade Commission,

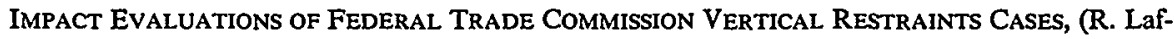
ferty, R. Lande \& J. Kirkwood, eds. 1984); T. Overstreet, Resale Price Maintenance: EcoNOMIC THEORIES AND EMPIRICAL EvIDENCE (Bureau of Economics Staff Report to the Federal Trade Commissioner 1983); see also Comanor \& Frech, The Competitive Effects of Vertical Agreements?, 75 AM. ECON. REV. 539 (1985) (investigating implications of vertical agreement requiring exclusive dealings between distributor and manufacturer); Marvel \& McCafferty, Resale Price Maintenance and Quality Certification, 15 RAND J. ECON. 346 (1984) (explaining use of resale price maintenance where no presale dealer services required); Mathewson \& Winter, An Economic Theory of Vertical Restraints, 15 RAND J. ECON. 27 (1984) (discussing externalities justifying use of vertical restraints). 
Telser's pathbreaking article in 1960,53 it has become commonplace for antitrust scholars to assert that resale price maintenance and, by the same general reasoning, nonprice restraints can be used to control freerider problems. Liebeler obviously accepts this literature and tries to use it against me. ${ }^{54}$ I myself have accepted it. ${ }^{55}$ Telser provided the basic material for the diagram in Figure One, which has undoubtedly appeared 10,000 times in hornbooks, law review articles and antitrust classrooms. Figure One illustrates that resale price maintenance (RPM), designed to control free riding, can actually be efficient because it increases output.

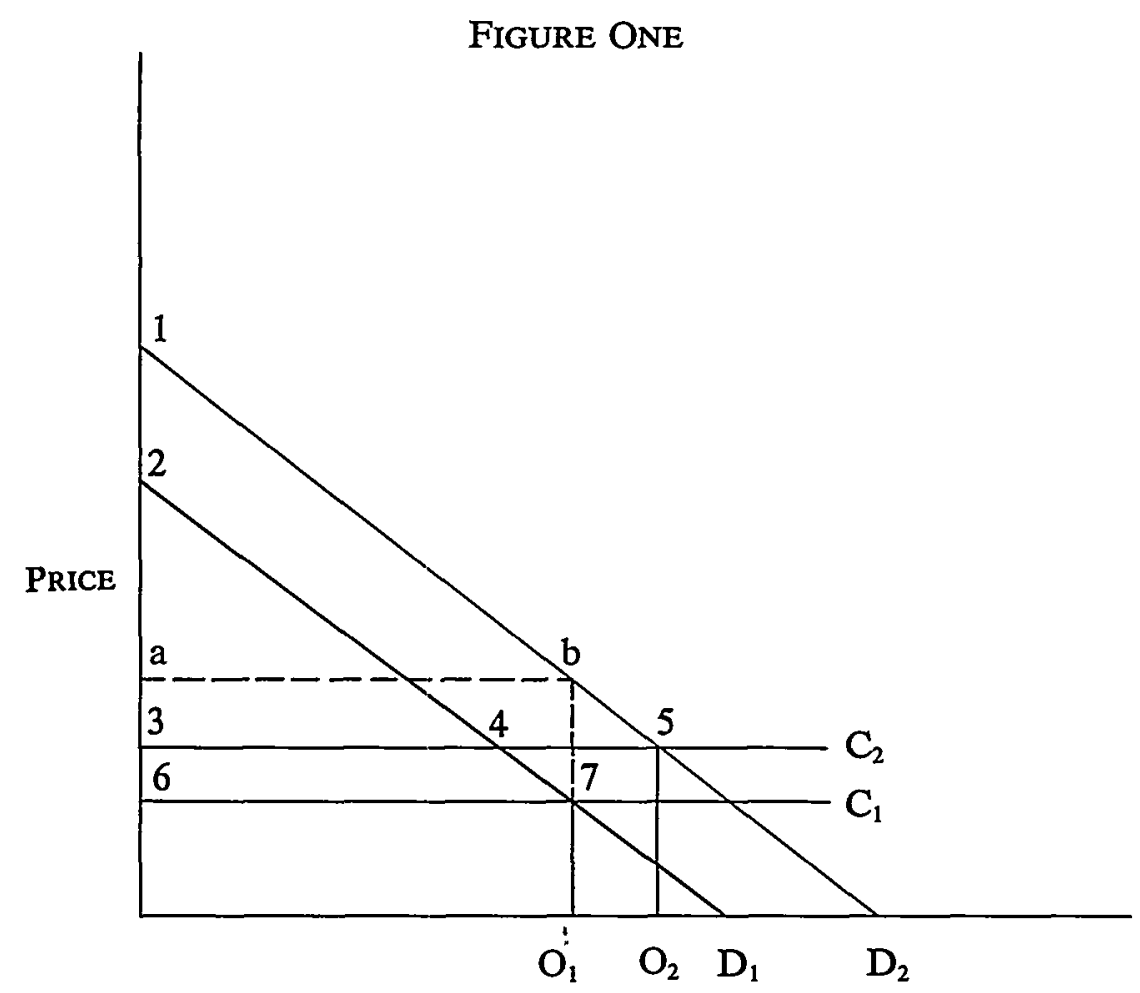

QUANTITY

$D_{1}$ shows the demand curve for a product before RPM is imposed. Output is equal to $0_{1}$, and consumers' surplus ${ }^{56}$ is equal to triangle 2-6-7. The resale price is $C_{1}$. When RPM is imposed at price $C_{2}$, dealers' costs

53. Telser, Why Should Manufacturers Want Fair Trade?, 3 J.L. \& Econ. 86 (1960).

54. Liebeler, supra note 1, at 811,817 .

55. See, e.g., H. HovenKamp, supra note $48, \S 9.2$, at 252-56.

56. Consumers' surplus is equal to the difference between the collective value that consumers place on a product and the amount they must pay for it. 
increase to that level as they compete against each other for sales by offering more point-of-sale services, making larger fixed-cost investments in facilities, and so on. Demand increases in response to these dealer investments. $D_{2}$, which is parallel to $D_{1}$, shows the demand curve after RPM is imposed. The curve is shifted to the right to illustrate the increased value that customers place on the additional services that result from RPM. Output has now increased to $\mathrm{O}_{2}$, higher than it was before RPM, even though price is also higher. Consumers are willing to pay more if they get more in return. Consumers' surplus under RPM equals triangle 1-3-5.

This is an impressive piece of geometry. I can remember being fairly awestruck when I was first exposed to it in law school in late 1977-the same semester that the Supreme Court decided Continental T.V., Inc. v. GTE Sylvania Inc., ${ }^{57}$ applying a rule of reason to vertical nonprice restraints. Yet-particularly in the absence of corroborating empirical evidence which has proven elusive-how much does the diagram tell about the real world? The answer, I now believe, is not very much.

Ever since the publication of Telser's 1960 article, ${ }^{58}$ advocates of the free-rider argument for RPM have generally assumed that demand curves $D_{1}$ (before $R P M$ ) and $D_{2}$ (under RPM) were parallel. This assumption reflects the rather odd belief that all customers place precisely the same value on the increased point-of-sale services that RPM produces. As a matter of geometry, it can be shown that if demand curves $D_{1}$ and $D_{2}$ are parallel, RPM that increases output will also increase consumers' surplus. ${ }^{59}$ Relymg on models like this, some writers virtually equate increases in output with increases im efficiency. ${ }^{60}$

As an empirical matter, the assumption of parallel demand curves seems heroic at best, ludicrous at worst. Some recent literature, particularly by Professors Comanor and Scherer, ${ }^{61}$ illustrates this. As a practical illustration, consider the market for personal computers. Some "marginal" consumers ${ }^{62}$ will have to be educated about why they need a

57. 433 U.S. 36,59 (1977).

58. Telser, supra note 53.

59. The simplest way to illustrate this is by looking at the horizontal dotted line $a-b$ on the graph, which illustrates what would occur if RPM raised price to such a level that output was precisely the same under RPM as before. In that case, the consumers' surplus triangle under RPM, 1-a-b, is precisely the same size as the consumers' surplus triangle before RPM, 2-6-7. Since triangle 1-3-5 is larger than triangle 1-a-b, it follows that consumers' surplus has increased under RPM.

60. See, e.g., Easterbrook, Vertical Arrangements and the Rule of Reason, 53 ANTITRUst L.J. 135, 140 (1984) (arguing that output-increasing vertical restraints are procompetitive).

61. See, e.g., Comanor, Vertical Price-Fixing, Vertical Market Restrictions, and the New Antitrust Policy, 98 HARv. L. REv. 983, 992-98 (1985); Scherer, The Economics of Vertical Restraints, 52 ANTITRUST L.J. 687, 700 n.23 (1983).

62. Marginal consumers are those who place the lowest value on the product. 
computer, what kind of computer they need, and how to operate it. Other consumers-perhaps business firms that own half a dozen personal computers and want to purchase more-already know exactly what they need. For them, the point-of-sale services are a waste of money. Figure Two depicts the more realistic assumption that different consumers value point-of-sale services at different amounts, and that the marginal consumers' surplus will increase the most from the point-of-sale services. In other words, marginal consumers are those most in need of the educational and other services supplied by the dealer.

\section{FIGURE Two}

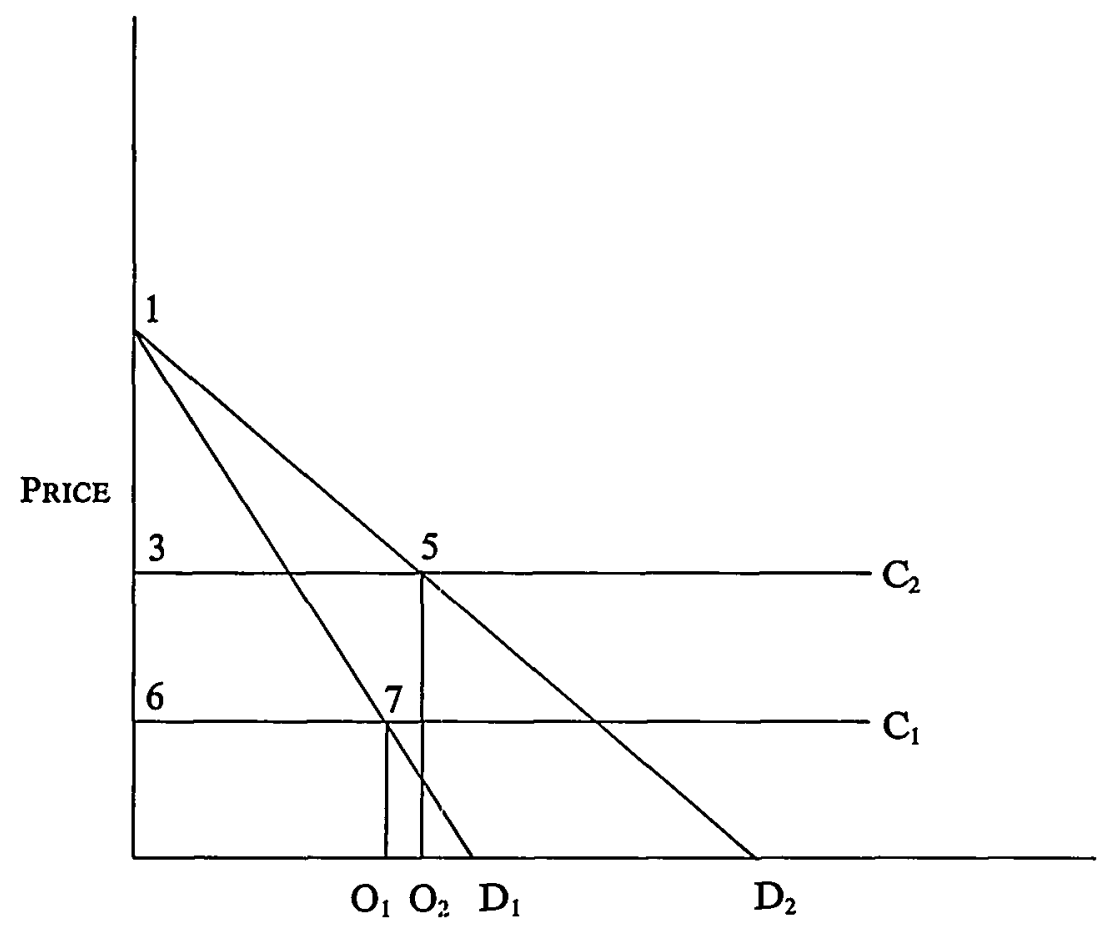

QUANTITY

Figure Two is like Figure One except that the shifted demand curve $D_{2}$, reflecting demand under RPM, is no longer parallel to $D_{1}$. Rather, it suggests that marginal consumers-those relatively low on the demand curve-profit greatly from $\mathbb{R P M}$. On the other hand, high-value consumers - those higher on the demand curve - profit relatively less from the kinds of services offered by RPM, and at the margin-the very topthey may not profit at all. 
Most importantly, once we throw away the assumption of parallel demand curves, the welfare effects of RPM become indeterminate. In Figure Two, the RPM increases output, but there is no necessary connection between output and efficiency. The efficiency of a practice is generally equal to the amount of economic surplus that it creates-the sum of consumers' surplus and producers' surplus. Although output has increased under RPM, consumers' surplus may actually have been reduced. Before RPM was in place, consumers' surplus equalled triangle 1-6-7. Under RPM, consumers' surplus is triangle 1-3-5, which in this particular illustration is smaller than triangle 1-6-7. Assuming that the manufacturer is earning monopoly profits, its surplus is larger by the distance from $0_{1}$ to $\mathrm{O}_{2}$ times the monopoly profits it is earning, but this may not be enough to offset the reduction in consumers' surplus. The dealers, which are in fierce competition with each other, are not earning a surplus, for they are competing away the higher retail price in increased point-of-sale services. As a result, RPM may be inefficient, even though it is being used to combat free riding and, inportantly, supplier output is higher under RPM than it had been before.

What does Figure Two prove? I make no grandiose claims for Figure Two, except this one: Figure Two proves that Figure One did not prove very much. Twenty-five years of theoretical argument supporting a rule of per se legality in RPM cases, it turns out, probably rested on a mistaken assumption about the shapes of demand curves.

Clearly the Chicago view on RPM is not ready to be turned into a rule of per se legality. ${ }^{63}$ Read together, Figures One and Two suggest that, as a matter of econounics alone, ${ }^{64}$ RPM should be governed by a rule of reason and the suppliers' inarket power ought to be an important ingredient in judicial analysis under that rule. The consumers in Figure Two who do not place a high value on point-of-sale services can be forced to pay for them only if there are no lower-priced alternatives. There would be no such alternatives only if the manufacturer inposing RPM liad substantial market power or the manufacturers in the market were using RPM collusively.

This illustration also suggests that economic tlieory in antitrust cases must be wielded more like a scalpel and less like an axe. Theory is inportant to cut away those large areas about which there has been wide-

63. Cf. Posner, The Next Step in the Antitrust Treatment of Restricted Distribution: Per Se Legality, 48 U. CHI. L. REv. 6, 23-25 (1981) (arguing that vertical restrictions on distribution should be declared legal per se).

64. I, perhaps unlike Professor Liebeler, believe that courts should continue to apply a rule of per se illegality, not because it is supported by any particular economic model, but because Congress continues to command it. See Hovenkamp, After Chicago, supra note 2, at 250-54. 
spread agreement and little coherent dissent. For example, unilateral conduct by firms not possessing monopoly power should be legal per se and naked price fixing should be illegal per se. Within the realm of the rule of reason, however, where both Aspen Skiing and Bonjorno lie, a broad range of theoretical questions must be treated as questions of fact. Admittedly, we will not always like the outcomes. We have our pet theories which we hold with religious fervor and cannot believe that any rational person would think differently. But losing once in a while is part of the price of democracy, and economists-certainly not any particular group of economists-are not yet the dictators of American antitrust policy. In my view, that is about all the "rehabilitation"65 that Aspen Skiing and Bonjorno need.

With Professor Areeda, I66-like Professor Liebeler ${ }^{67}$-have expressed doubt about the market definition in Aspen Skiing. That issue, however, is irrelevant here. The market definition question was not preserved and was not before the Supreme Court. Given that fact, I believe that the Supreme Court was correct not to permit any doubts it may have had about the relevant market to color its analysis of the jury's right to find monopolistic conduct. Even Chicago School judges agree that judicial economy is a sufficient defense for such a rule, regardless of whether it benefits plaintiffs or defendants in antitrust cases. ${ }^{88}$ The relevant policy question at this point is not whether Ski Co was an illegal monopolist, but whether future firms that $d o$ have monopoly power can be condemned for doing what Ski Co did.

\section{On Raising Rivals' Costs and the Per Se Rule}

I an1 perplexed by Professor Liebeler's criticism of my suggestion that no one has ever provided a rational efficiency explanation for contracts in which "a supplier promises to charge higher prices to the contracting firn's competitors than it charges to the contracting firm."69 Liebeler suggests that the efficiency explanation is both rational and obvi-

65. See Liebeler, supra note 1 , at 801 .

66. See P. AREeda \& H. Hovenkamp, supra note $44, \$ 518.1 \mathrm{~h}$.

67. See Liebeler, supra note 1, at 811.

68. See, e.g., Marrese v. American Academy of Orthopaedic Surgeons, 470 U.S. 373 (1985) (reversing Judge Posner's decision that res judicata barred federal antitrust claim in wake of prior Illinois state court judgment on same facts); Premier Elec. Constr. Co. v. National Elec. Contractors Ass'n, Inc., 814 F.2d 358 (7th Cir. 1987) (Easterbrook, J.) (holding that judicial economy would be best served if one who opted out of a class action was not later given the benefit of offensive collateral estoppel).

69. Hovenkamp, Antitrust Policy, Restricted Distribution, and the Market for Exclusionary Riglits, 71 MINN. L. REv. 1293, 1317 (1987). 
ous-to discourage free riding by marginal resellers. ${ }^{70}$

Professor Liebeler misreads my statement. I proposed per se condemnation of agreements under which a supplier promises "to charge higher prices to the contracting firm's competitors." ${ }^{\prime}$ Liebeler responds by concluding that there might be an efficiency explanation for a contract that commands a higher price to a particular free-riding competitor. The argument I made and the one he attacks are very different. Conceding for the moment that in Klor's Inc. v. Broadway-Hale Stores, Inc. ${ }^{72}$ it might have been efficient for Broadway-Hale to contract with Maytag for higher prices to Klor's, a free-riding neighbor, that contract is altogether different from an arrangement in which Broadway-Hale obtains a commitment from Maytag to charge higher prices to every retailer in San Francisco. The latter practice creates a price umbrella that permits the retailer to raise its own price as well.

Even as Professor Liebeler misreads my statement, it is not obviously wrong. Giving Professor Liebeler the benefit of every doubt, I suppose that we may be quibbling about the word "efficient." Choosing among a half-dozen arrangements, the one that results in the second largest welfare loss is admittedly "efficient" by comparison with the one that produces the largest welfare loss. There are several obvious solutions to the Klor's free-rider problem that Liebeler describes: (1) resale price maintenance, illegal per se but nevertheless often efficient; (2) territorial or locational restrictions; (3) refusals to deal with free riders; (4) contractual requirements of point-of-sale services; and (5) more complete vertical integration into retailing. Professor Liebeler's suggestion that a contract between the full-service dealer and a supplier requiring the supplier to charge more to a free-riding dealer is "efficient" may mean no more than that it is not the most harmful of these alternatives. But such a contract poses extraordinary problems for the supplier. The supplier must compute the price differential precisely. If he calculates it too high, he may create a price umbrella that will permit the full-service dealer to charge higher prices at the supplier's expense. ${ }^{73}$ If the supplier charges too little, he will not eliminate the free riding but will only reduce it.

Importantly, a policy of differential pricing as Professor Liebeler describes it is best for the supplier whether or not he does so by agreement with one or more dealers. Perhaps some high-quality, full-service retailers will refuse to carry a product unless they can be guaranteed a certain amount of protection from free riding. This explains many vertical price

70. Liebeler, supra note 1 , at 817 .

71. Hovenkamp, supra note 69 , at 1317.

72. 359 U.S. 207 (1959).

73. Assuming, of course, that competition does not restrain them. 
maintenance agreements and territorial or other distributional restraints. It might even be efficient for a dealer to insist that competing dealers who do not advertise or who do no warranty work must pay a premium for the product. It still escapes me, however, why it would be efficient for one dealer and a supplier to agree that another, particular supplier be charged higher prices, even if that supphier is currently engaged in substantial free riding. By "efficient" here I mean not that the solution is not the worst possible one, but rather that one could not come up with a better one-or one equally good and clearly less anticompetitive-with just a few moments thought.

All of this is quibbling, however, because in addition to misreading my statement, Professor Liebeler did not address my real point. My point was not that no one could ever concoct a plausible efficiency explanation of a contract in which a supplier promises one dealer that it will charge higher prices to its competitors. Rather, my contention was that such contracts should be illegal per se under the antitrust laws-the risks are simply too high when compared with dangers to competition that are relatively obvious.

\section{CONCLUSION}

Professor Liebeler suggests that a good Chicagoan should take comfort in the fact that while neither John Wiley nor I agree witli Chicago, neither do we agree with each other. That argument is supported by neither logic nor experience-quite the contrary. Absence of debate and controversy is far more characteristic of dead orthodoxy than of new ideas. The Chicago School is not dead orthodoxy. It is a worthy opponent, and like most worthy opponents, the Chicago School is attacked by liberals, Marxists, institutionalists, Austrians and evangelicals, most of whom disagree with each other across a wide range of ideas. So much the better for the debate. 